\section{Drastic Changes of Endogenous Phytohormones in Dormant Gladiolus Corms Treated with Methyl Disulfide}

Takashi Hosoki

Faculty of Agriculture, Shimane University, Nishikawatsu-cho 1060, Matsue, Shimane 690, Japan

Additional index words. auxin-like substances, dormancy, inhibitors, Gladiolus $\times$ Tubergenii

Abstract. Effects of methyl disulfide (MeS $)$ on sprouting and phytohormones in dormant corms of spring-flowering gladiolus (Gladiolus $\times$ Tubergenii Hort. 'Charm') were studied. Corms treated with $\mathrm{MeS}_{2}$ sprouted 30 days earlier than nontreated corms. The concentrations of endogenous promoters in the corm tissue increased and inhibitors decreased within $24 \mathrm{~h}$ of treatments. High concentration of inhibitors were present in the nontreated corms.

The duration of corm dormancy of springflowering gladiolus was shortened by hightemperature storage (Hosoki, 1985a) or treatment with gases (ethanol, acetaldehyde, ethylene, or CO) (Hosoki, 1985b). Methyl disulfide $\left(\mathrm{MeS}_{2}\right.$ ) derived from garlic (Allium sativum L.) was effective in shortening dormancy of corms of spring-flowering gladiolus (Hosoki et al., 1986). Hosoki (1985a) reported that high-temperature storage gradually increased auxin-like substances and decreased inhibitors of Avena coleoptile growth in corm tissue stored for 25 to 50 days. My report deals with changes in endogenous phytohormones in the dormant corms of spring-flowering gladiolus treated with $\mathrm{MeS}_{2}$.

\section{Materials and Methods}

'Charm' gladiolus corms were lifted on Hachijo Island, Tokyo, at the end of May and were sent to Shimane Univ., Matsue, Shimane, Japan, on 5 June. Twenty corms (averaging 4 $\mathrm{cm}$ in diameter, $\approx 17 \mathrm{~g}$ fresh weight) were placed in a sealed 6-1 iter glass vessel containing $200 \mathrm{ml} 1 \%$ aqueous $\mathrm{MeS}_{2}$ at 20C. The corms were placed on a wire net in the vessel to avoid direct contact with the solution (Hosoki et al., 1986). The corms were removed from the vessel $4 \mathrm{~h}$ later, placed on a laboratory table, and stored $24 \mathrm{~h}$ at $25 \mathrm{C}$. Ten of the corms were planted in a tray containing sandy loam soil, maintained at $25 \mathrm{C}$ to evaluate bud sprouting, and watered every other day. Sprouting was defined as a bud on the corm elongated to $1 \mathrm{~cm}$. The remaining 10 corms were used for analysis of endogenous phytohormones (auxinlike substances and inhibitors). Nontreated (control) and $\mathrm{MeS}_{2}$-treated corms were handled similarly.

After removal of scale leaves, $10 \mathrm{~g}$ of corm tissue ( $1 \mathrm{~g}$ from each of 10 corms) were

Received for publication 17 Feb. 1995. Accepted for publication 15 May 1995. The cost of publishing this paper was defrayed in part by the payment of page charges. Under postal regulations, this paper therefore must be hereby marked advertisement solely to indicate this fact.

HortScience, Vol. 30(6), OCtOBer 1995 chromatography with a solvent system consisting of 10 iso-propanol : 1 ammonia water : 1 water (by volume) and bioassayed by an Avena coleoptile straight growth test (Tsukamoto and Konoshima, 1972). Growth activities of phytohormones were represented in a histogram in which growth promotion and inhibition of eight Avena coleoptiles incubated in distilled water containing a paper strip of each $\mathrm{Rf}$ value were compared by least significant difference (LSD) test to those of eight Avena coleoptiles incubated in distilled water containing unused paper strip. The distance of solvent developed on the paper chromatogram was partitioned into tenths from the origin, and each partition (zone) was defined as a $\mathrm{Rf}$ value from 0.1 to 1.0 . The mean length of the coleoptiles elongated in distilled water containing an unused paper strip was rated at $100 \%$.

\section{Results and Discussion}

sampled, extracted at $4 \mathrm{C}$ with $80 \%$ methanol for $24 \mathrm{~h}$, and fractioned (Hosoki. 1985a). The acidic fraction then was separated by paper

Bud sprouting. Corms treated with $\mathrm{MeS}_{2}$ sprouted 30 days earlier than nontreated con-

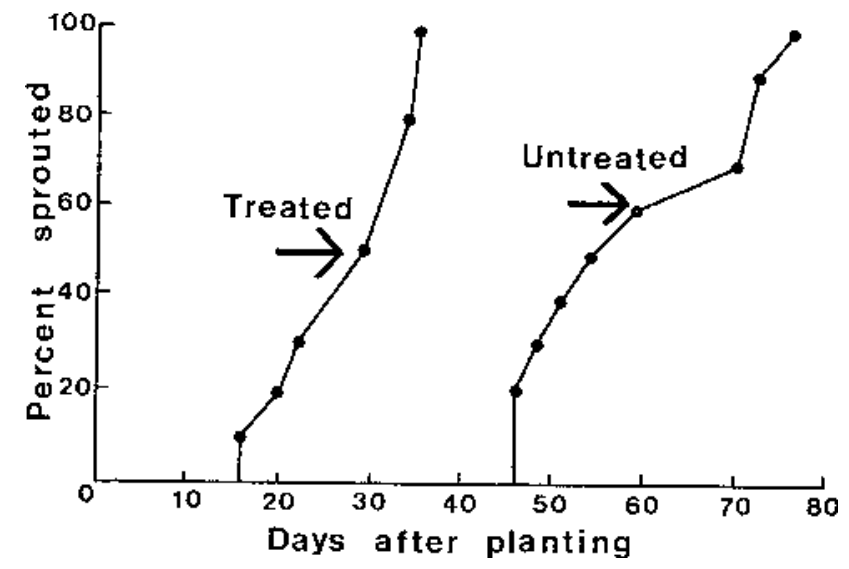

Fig. 1. Effect of methyl disulfide $\left(\mathrm{MeS}_{2}\right)$ on sprouting of dormant corms of spring-flowering 'Charm' gladiolus. Arrows indicate the mean number of days to bud sprouting.

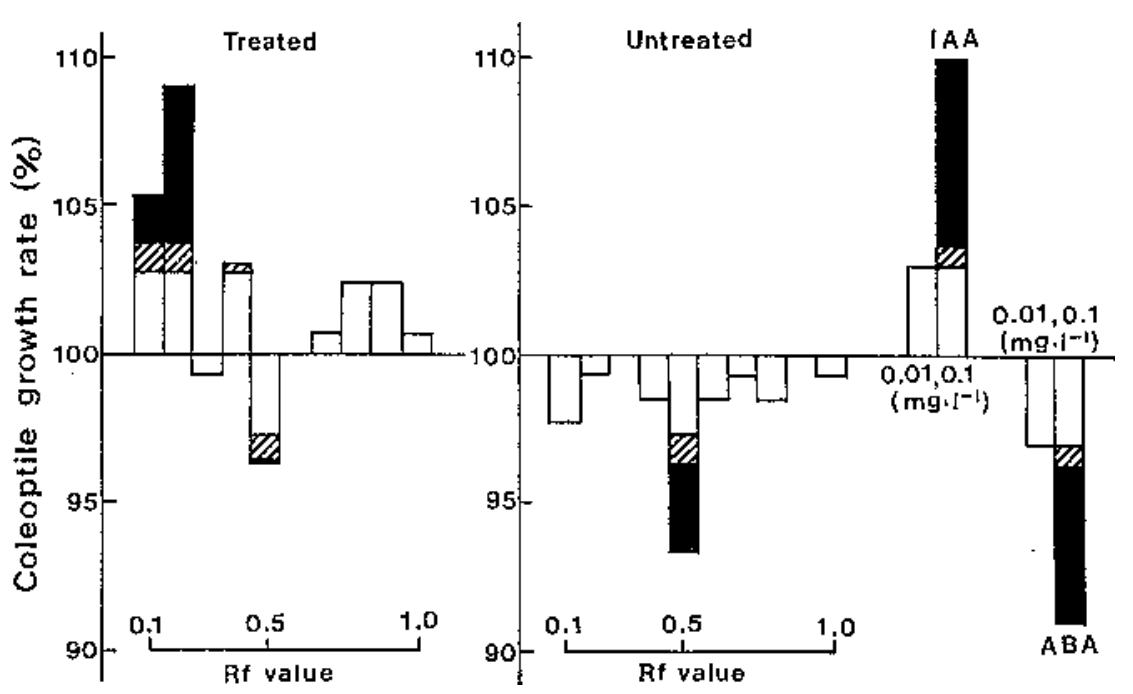

Fig. 2. Effect of auxin-like substances and inhibitors extracted from methyl disulfide $\left(\mathrm{MeS}_{2}\right)$-treated and nontreated corms, as quantified with an Avena coleoptile straight growth test. Indoleacetic acid (IAA); abscisic acid (ABA ). Dark and hatched areas represent significant $(P \leq 0.01$ and 0.05 , respectively) growth promotion and inhibition of Avena coleoptiles; mean growth length of coleoptiles incubated in distilled water containing unused paper strip was taken as $100 \%$. 
trol corms (Fig. 1). The mean number of days to sprouting was 27 and 58, respectively (significantly different at $P \leq 0.001$ by $t$ test).

Auxin-like substances and inhibitors. Auxin-like substances were detected at Rf 0.1 . $0.2,0.4,0.7,0.8,0.9$, and 1.0. of which Rf 0.1 and 0.2 were active $(P \leq 0.01$ by LSD test) in corms treated with $\mathrm{MeS}_{2}$ (Fig. 2). The maximum activity of $\operatorname{Rf} 0.2$ was equivalent to a concentration of $0.1 \mathrm{mg} 1 \mathrm{H}$-indole-3-acetic acid (indoleacetic acid)/liter. Inhibitors were detected at $\mathrm{Rf} 0.5$. The activity was slightly greater than that of $0.01 \mathrm{mg}$ abscisic acid (ABA)/liter. In control corms, no auxin-like substances were detected, but inhibitors were detected at most $\mathrm{Rf}$ values. The maximum inhibitor activity at $\mathrm{Rf} 0.5$ of nontreated corms was higher than that of $\mathrm{MeS}_{2}$. Growth promot- ers increase and inhibitors decrease gradually during corm storage before termination of dormancy and during high-temperature storage of gladiolus (Hosoki, 1985a). In $\mathrm{MeS}_{2}$ treated gladiolus corms, these changes occurred within $24 \mathrm{~h}$ of treatment. To our knowledge, such a drastic change in the concentration of endogenous phytohormones in corms has not been reported before. Such a rapid change and the corresponding increases in respiration rate (Hosoki, 1989) are involved in the release from dormancy of $\mathrm{MeS}_{2}$-treated corms. Major phytohormones involved should be identified with further research.

\section{Literature Cited}

Hosoki, T. 1985a. Effect of endogenous growth regulators during storage of dormant corms of spring-flowering gladiolus. HortScience 20:366367.

Hosoki, T. 1985b. Effect of ethanol and other gaseous compounds on breaking corm dormancy of spring-flowering gladiolus and accelerated flowering. Bul. Faculty Agr. Shimane Univ. 19:1116.

Hosoki, T. and T. Kubara. 1989. Breaking corm dormancy and accelerated flowering of gladiolus with methyl disulfide treatment. HortScience 24:968-971.

Hosoki, T., Y. Sakai, M. Hamada, and K. Taketani. 1986. Breaking bud dormancy in corms and trees with sulfide compounds in garlic and horseradish. HortScience 21:114-116.

Tsukamoto, Y. and H. Konoshima. 1972. Changes of endogenous growth regulators in the gladiolus corm during dormancy. Physiol. Plant. 26:244-249. 